\title{
Screening for Plasmid-Mediated Multidrug Resistant Bacteria in Ikpoba River Water Samples
}

\author{
Akpe Azuka Romanus ${ }^{*}$, Okwu Grace Ifeoma, Esumeh Frederick Ikechukwu, Femi, Imah Justus
}

Department of Microbiology, Ambrose Alli University, Ekpoma, Nigeria

Email address:

lordromis@yahoo.co.uk(A.A. Romanus)

${ }^{*}$ Corresponding author

\section{To cite this article:}

Akpe Azuka Romanus, Okwu Grace Ifeoma, Esumeh Frederick Ikechukwu, Femi, Imah Justus. Screening for Plasmid-Mediated Multidrug Resistant Bacteria in Ikpoba River Water Samples. International Journal of Microbiology and Biotechnology.

Vol. 3, No. 2, 2018, pp. 31-35. doi: 10.11648/j.ijmb.20180302.11

Received: March 30, 2018; Accepted: April 16, 2018; Published: May 7, 2018

\begin{abstract}
The abuse and extensive use of antimicrobial agents by humans may increase resistant bacteria populations in the aquatic environment. The discharge of untreated wastewater into rivers and other non-point sources of pollution have led to the antibiotic resistant bacteria in the environment, particularly in surface waters. Studies on river water pollution and their implication to public health has been ongoing. Screening for multi-drug resistant bacterial status of Ikpoba River in Benin City, Nigeria was carried out using standard microbiological and physicochemical procedures. The bacteria isolated from the river water samples were E. coli, Salmonella sp, Vibrio sp, Staphylococcus aureus, and Streptococcus faecalis. The antibiotics susceptibility testing of the isolates revealed a multi-drug resistant status for Staphylococcus aureus and Streptococcus faecalis. The plasmid profile of these multi-drug resistant isolates was determined and results revealed that both isolates harboured plasmid of size $4.5 \mathrm{~kb}$. Antibiotic susceptibility of the isolates when cured of plasmid revealed loss of resistance to over $75 \%$ of the antibiotics they were originally resistant to. The microbial and physicochemical properties of the river showed that it is unfit for human consumption. The Plasmid mediated multidrug resistant status of some of the isolates is a threat to chemotherapy and is a cause for public health concern.
\end{abstract}

Keywords: River Water, Antibiotics, Pollution, Multi-drug Resistance, Plasmid

\section{Introduction}

Plasmid is a small DNA molecule located within a cell that is capable of independent replication. They are separated from the chromosomal DNA. Plasmid often carries genes that may benefit the survival of the host organism in antibiotic resistance. Chromosomes are big and contain all the essential genetic information for the survival of an organism under normal conditions. Plasmids, besides their small sizes, contain additional genes that are beneficial to the organisms under certain situations or conditions [1].

The abuse and extensive use of antimicrobial agents by humans may increase resistant bacteria populations in the aquatic environment. The discharge of untreated wastewater into rivers and other non-point sources of pollution have led to the antibiotic resistant bacteria in the environment, particularly in surface waters [2].Water constitutes not only a way of dissemination of antibiotic resistant organisms among human and animal population, but also the route by which resistance genes are introduced in natural bacterial ecosystem. Many of these bacteria harbour antibiotic resistance genes mainly inserted in plasmid, transposant or integron able to be transferred among water and soil bacteria community via horizontal gene transfer [3].

Due to indiscriminate use of broad spectrum antibiotic against infections in clinical setting, agriculture, and fish hatcheries, antibiotic resistance has dramatically increased among Staphylococcus aureus and Streptococcus species. In particular, Staphylococcus aureus has acquired resistance against the commonly abused broad spectrum antibiotic such as augmentin, ofloxacin, streptomycin, amoxicillin and ciprofloxacin that are used alone or in combination for treatment of common infections through self - medications. Some of these drugs are being excreted during treatment mostly as active compounds, therefore their biological action is not limited to the therapeutic site, but it is further moved into the environment. Water environment is the ideal medium 
for the aggregation and dissemination of antibiotics, antibiotic - resistant bacteria and antibiotic resistance genes, which poses a serious threat to human health if ingested by the user [4].

Water is one of the most bacterial habitats on earth, a major way of disseminating microorganisms in nature and has been recognized as a significant reservoir of antibiotic resistant microorganisms $[5,6]$.

Numerous studies have demonstrated the importance of the environmental setting, e.g. water or soil on the cycling of antibiotic resistance in nature, either because antibiotic resistance mechanism can originate in environmental bacteria or because human and animal commensals and pathogens can contaminate the environment [7].

Ikpoba River is a fourth order stream located in Benin City, Edo State, Nigeria. Ikpoba River receives a variety of waste ranging from agriculture, domestic, industrial and from other sources and these wastes introduce foreign microorganisms into the river. Some of these organisms have serious medical and economic implications. The threat is further compounded by the increasing incidence of isolates with drug resistance [8]. The implication of the picture painted above is that, antibiotics resistance organisms are not only distributed in hospital wastewaters but also in animal production wastewaters, sewage, wastewater treatment plants, surface water, groundwater, and even drinking water [9]. This has further complicated the treatment of infections.

Other sources of pollution of Ikpoba River include wastes from abattoir, faecal matter from people living within the vicinity, pollution from laundry activity such as washing and bathing etc. all these are implicated in the introduction of antibiotic resistant isolates in Ikpoba River.

A lot of research works have been undertaken on Ikpoba River, some of which include the effects of brewery effluents on the water quality and rotifers of Ikpoba River [10]. The effects of brewery effluents on the microbiological quality of Ikpoba River, and the surrounding borehole water in Benin City have also been reported [11].Also worked on was the influence of brewery discharge on the microbiological and physicochemical quality of Ikpoba River [12], but no work has been conducted on plasmid - mediated multidrug resistant bacteria in Ikpoba River water samples.

\section{Methods}

\subsection{Sample Collection, Bacterial Isolation, Characterisation and Identification}

Water samples were collected from the waste discharge point, upstream and down stream portions of Ikpoba River and inoculated in duplicates onto sterile MacConkey agar, nutrient agar and Salmonella Shigella agar plates. The plates were then incubated for $24-48 \mathrm{~h}$ at a temperature of $37^{\circ} \mathrm{C}$. Thereafter emerging colonies were characterized and identified. The phenotypic and biochemical characteristics used to characterize and identify bacterial isolates included Gram staining, colonial appearance, motility, urease, catalase, indole, oxidase, citrate, methyl red, voges proskaeur and sugar fermentation. These tests were performed and emerging colonies identified using standard methods [13].

\subsection{Antibiotic Susceptibility Testing}

Antibiotics susceptibility testing was carried out on the isolates using the disc diffusion method $[14,15]$. Mueller Hinton (MH) agar was prepared according to the instructions of the manufacturer. The commercially prepared antibiotic disc (Lab M) was used for the study. The disc consisted of the following antibiotics with their concentrations: pefloxacin, $10 \mu \mathrm{g}$; gentamycin, $10 \mu \mathrm{g}$, amoxicillin, $30 \mu \mathrm{g}$; ciprofloxacin, $10 \mu \mathrm{g}$; streptomycin, $30 \mu \mathrm{g}$; cotrimoxazole,

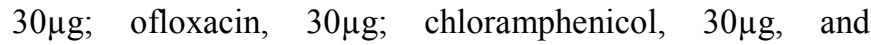
augmentin, $25 \mu \mathrm{g}$. The antibiotics discs were placed on $\mathrm{MH}$ agar plates earlier seeded with cell suspension of the isolates with a turbidity of $0.5 \mathrm{McF}$ arland standards and incubated at $37^{\circ} \mathrm{C}$ for $24 \mathrm{~h}$. The zones of inhibition were measured and recorded. The antibiotic sensitivity test was termed susceptible when the recorded zones of inhibition ( $\mathrm{mm})$ were $\geq 11$ and resistant when the zones of inhibition to the antibiotic was $\leq 9[16]$.

\subsection{Plasmid Profile Analysis}

Plasmid curing was carried out on the multi-drug resistant isolates using the methods earlier described by [17] and used by [18]. The curing agent used was sodium dodecyl sulphate (SDS). Physical evidence for the presence or loss of plasmid(s) in cured and non-cured isolates was obtained by alkaline phosphate method of rapid DNA isolation technique $[19,20]$. This involved four basic steps - cell harvest, lysis, deproteination and decontamination. The plasmids were characterized using agarose gel electrophoresis [21]. The molecular weights of plasmids were visualized using UV transilluminator (AlphaImager TM 2200) at 302-365nm. Thereafter the susceptibility patterns of the plasmid cured isolates was performed and compared with the original isolates.

\section{Results and Discussions}

\subsection{Bacterial Isolates and Their Antibiotics Susceptibility Patterns}

The bacterial isolates from this study were Escherichia coli, Salmonella sp, Vibrio sp, Streptococcus faecalis and Staphylococcus aureus. Escherichia coli was the most predominant bacterial isolate followed by Salmonella sp. These and their corresponding antibiotics susceptibility patterns are shown in Table 1. It was observed that two of the isolates (Streptococcus faecalis and Staphylococcus aureus) were multidrug resistant. These two isolates were resistant to the commonly abused broad spectrum antibiotics such as augmentin, gentamicin, perfloxcin, ofloxacin, streptomycin, amoxicillin, chloramphenicol used for treatment of common infections such as urinary tract infections (UTI), typhoid fever and other sexually transmitted diseases (STDs). The presence of multi-drug resistant bacteria agrees with the report [22] that 
freshwater environment represent a potential reservoir of antibiotic resistant bacteria. The presence of antibiotic resistant bacterial isolates in environmental samples is attributed to the massive exposure of the environment to antibiotics through the use and misuse of antibiotics by human and in veterinary medicine [23]. This implies that in near future organisms would begin to acquire resistance against the newly synthesized antibiotics and it poses a serious threat to the future generation if no measures are put in place.

\subsection{Plasmid Profiling}

The plasmid profile analysis revealed that two of the isolates (Streptococcus faecalis and Staphylococcus aureus) had plasmids of the same size $(4.5 \mathrm{~kb})$ as shown in Figure 1 . The plasmid curing experiment was successful as shown in Figure 2. The success of this curing agrees with previous reports of elimination of plasmids using DNA intercalating agents -SDS, acridine orange, ethidium bromide and other agents [24, 25].

Table 2 showed the antibiotic susceptibility patterns of the two plasmid-cured multi-drug resistant isolates. It revealed loss of resistance to majority of the antibiotics.

The presence of plasmids aligns with earlier reports that small DNA molecules known as plasmids are the key culprits in spreading the major global health threat of antibiotic resistance [26]. Plasmids are thought of as being important "vehicles" that transfer resistance genes between bacteria. Also, their number (plasmid copies) play a critical role in imparting resistance and other characteristics to the organisms. The post plasmid curing antibiotics susceptibility test conducted on the two multidrug resistant isolates revealed that resistance to most of the antibiotics was lost indicating that it was plasmid mediated. This consolidated the fact that plasmids play a significant role in antimicrobial resistance. The source of this is attributed to routine discharge of antibiotics and resistance genes from wastewater or runoff from livestock facilities and agriculture. Elevated levels of antibiotics resistance genes in aquatic environments are correlated to their proximity to anthropogenic activities.

Apart from resistance conferred by mutation, antibiotics resistance determinants in pathogenic bacteria could also originate from non-clinical environment [2]. This also agrees with the findings in this research carried out on Ikpoba River isolates.

Table 1.Antibiogram of Bacterial Isolates from Ikpoba River Water Samples.

\begin{tabular}{lll}
\hline Isolates & Resistance To: & Susceptible To: \\
\hline Staphylococcus aureus & $\begin{array}{l}\text { Augmentin, gentamycin, pefloxacin, ofloxacin, streptomycin, } \\
\text { amoxicillin, chloramphenicol and cotrimoxazole }\end{array}$ & Ciprofloxacin \\
Streptococcus faecalis & $\begin{array}{l}\text { Chloramphenicol, cotrimoxazole, ofloxacin, pefloxacin, } \\
\text { gentamycin, augmentin, sparfloxacin, amoxicillin }\end{array}$ & Ciprofloxacin and streptomycin \\
Vibriosp & Amoxicillin & $\begin{array}{l}\text { Sparfloxacin, augmentin, gentamycin, pefloxacin, ofloxacin, } \\
\text { cotrimoxazole, streptomycin, chloramphenicol, ciprofloxacin } \\
\text { Salmonellasp }\end{array}$ \\
Escherichia coli & Streptomycin and chloramphenicol & $\begin{array}{l}\text { Ofloxacin, pefloxacin, amoxillin, augmentin, sparfloxacin, } \\
\text { cotrimoxazole, ciprofloxacin }\end{array}$ \\
Ciprofloxacin & $\begin{array}{l}\text { Sparfloxacin, augmentin, gentamycin, pefloxacin, } \\
\text { cotrimoxazole, streptomycin, chloramphenicol, amoxicillin }\end{array}$ \\
\hline
\end{tabular}

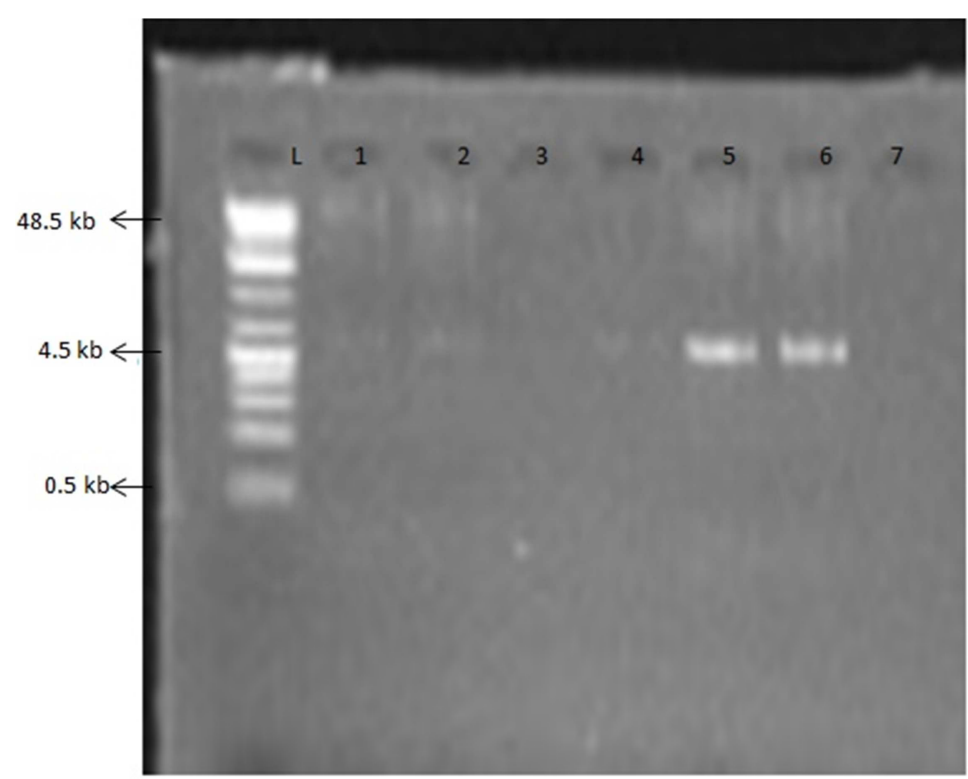

Figure 1. Plasmid profile of multi-drug resistant bacterial isolates analyzed with $0.8 \%$ agarose gel electrophoresis stained with ethidium bromide. L is $0.5 \mathrm{~kb}$ 48.5kb DNA ladder. Samples 5 and 6 are positive for plasmid with bands at 4.5kb. Samples 1, 2, 3, 4 and 7 are no DNA template control.

Key

$5=$ Staphylococcus aureus; $6=$ Streptococcus faecalis 


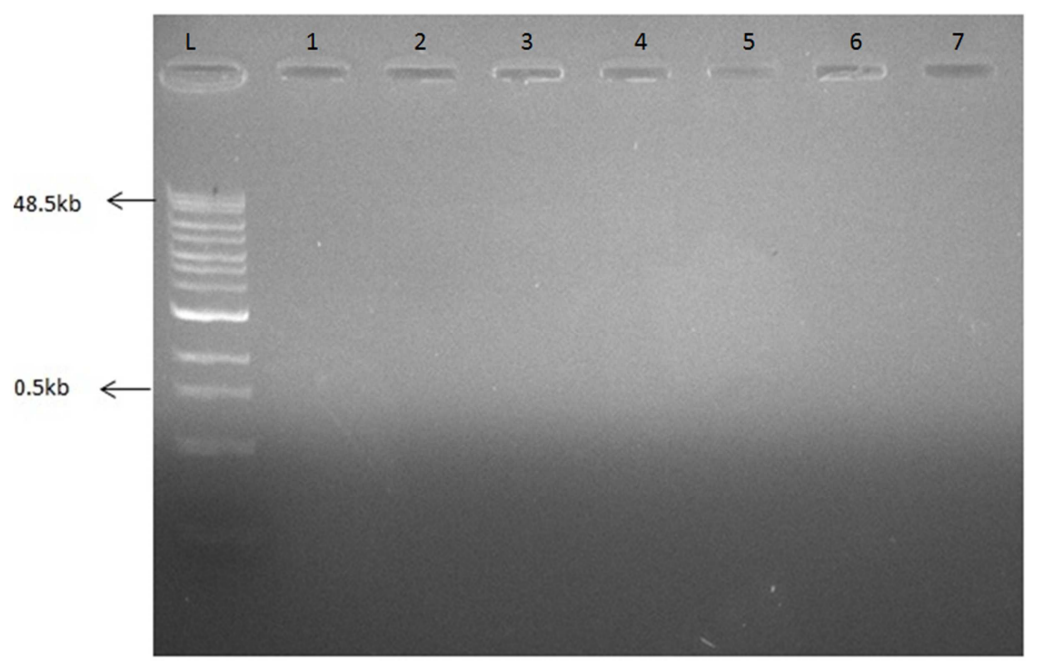

Figure 2. Plasmid profile (after curing) of multi-drug resistant bacterial isolates analyzed with $0.8 \%$ agarose gel electrophoresis stained with ethidium bromide. $L$ is $0.5 \mathrm{~kb}-48.5 \mathrm{kbDNA}$ ladder (molecular marker).Samples 5 and 6 shows no plasmid after curing. Samples 1, 2, 3, 4 and 7 are no DNA template control.

Key

$5=$ Staphylococcus aureus

$6=$ Streptococcus faecalis

Table 2.Antibiogram of Streptococcus faecalis and Staphylococcus aureus pre-and post Plasmid Curing.

\begin{tabular}{lllll}
\hline \multirow{2}{*}{ Isoltes } & Resistance To: & Susceptible To: & \\
\cline { 2 - 5 } & BeforeCuring & AfterCuring & BeforeCuring & AfterCuring \\
\hline $\begin{array}{l}\text { Staphylococc } \\
\text { us aureus }\end{array}$ & $\begin{array}{l}\text { Augmentin, gentamycin, pefloxacin, } \\
\text { ofloxacin, streptomycin, amoxicillin, } \\
\text { chloramphenicol cotrimoxazole }\end{array}$ & $\begin{array}{l}\text { Streptomycin and } \\
\text { amoxicillin }\end{array}$ & Ciprofloxacin & $\begin{array}{l}\text { Augmentin, gentamycin, pefloxacin, ofloxacin, } \\
\text { Ciprofloxacin, chloramphenicol and cotrimoxazole }\end{array}$ \\
$\begin{array}{l}\text { Streptococcus } \\
\text { faecalis }\end{array}$ & $\begin{array}{l}\text { Chloramphenicol, cotrimoxazole, } \\
\text { ofloxacin, pefloxacin, gentamycin, } \\
\text { augmentin, sparfloxacin, amoxicillin }\end{array}$ & Chloramphenicol & $\begin{array}{l}\text { Ciprofloxacin and } \\
\text { streptomycin }\end{array}$ & $\begin{array}{l}\text { Ciprofloxacin, streptomycin cotrimoxazole, } \\
\text { ofloxacin, pefloxacin, gentamycin, augmentin, } \\
\text { sparfloxacin, and amoxicillin }\end{array}$ \\
\hline
\end{tabular}

\section{Conclusion}

The research has shown that some of the isolates of water samples collected from Ikpoba River, Benin City, Edo State, Nigeria had a multidrug resistant property necessitated by plasmid. This would hamper the successful use of antibiotics for treating infectious diseases. Though antibiotics are still effective for treating many bacterial infections, many strains are becoming increasingly difficult to treat and therapeutic options are getting fewer and this poses a serious health threat to the populace. The isolates could have acquired the resistance by horizontal gene transfer through conjugation because large scales of antibiotics are used in aquaculture and poultry farming. Some of these wastes are drained into river through runoff and all these predispose the environment to antibiotics thereby resulting in resistance of bacterial isolates.

Industries should endeavour to treat their wastewater before discharge as some of the disinfectant used in the factory could confer resistance to organisms. Also, the aquaculturists and poultry farmers that live within the vicinity of the rivers should avoid the abuse of antibiotics since the effect of some of these therapeutic agents do not end at the very site of action; the residual effect ends in the environment. This could help to prevent the widespread of resistance found in bacteria and reduce the risk of treatment failures.

\section{References}

[1] Caro, L., Chruchwar, G. D., \& Chandler, M, (1984). Study of plasmid replication in vivo. Methods in Microbiol. 17 72-122.

[2] Magiorakos, A.P., Srinivasan, A., Carey, R.B., Carmeli, T., Falagas, M.E. (2012). Multidrug Resistance, Extensively drug-resistance and Pandrug-Resistance Bacteria in International Expert Proposal for Interim Standard Definitions for Acquired Resistance. Clinical Microbiology Infection 18: 269-281.

[3] Messi, P., Guerrier, E., Bondi, M. (2005). Antibiotic Resistance and Antibacterial Activity in Heterotrophic Bacteria of Mineral Water Origin. Science Total Environment 346: 213-219.

[4] Forsberg, K.J., Reyes, A., Wang, B., Selleck, E.M., Sommer, M.O. and Dantas, G. (2012). The Shared Antibiotic Resistance of Soil Bacteria and Human Pathogues. Science (337): 11101111.

[5] Baquero, F., Martinez, J.L. and Canton, R. (2018). Antibiotic Resistance in Water Environments.Correct Opinion Biotechnology (19): 260-265. 
[6] Rizzo, L., Manaia, C., Merlin, C., Schwartz, T., Dagot, C., Ploy, M.C., Michael, I. and Fatta-Kassinos, D. (2013). Urban Wastewater Treatment Plants as Hotspots for Antibiotics Resistance Bacteria and Genes Spread into the Environment. A Review. Science Total Environment (447): 345-360.

[7] Allenn, H.K., Donato, J., Wang, H.H., Cloud-Hansen, K.A., Davies, J., and Handelsman, J. (2010). Call of the Wide Antibiotic Resistance Genes in Natural Environments. National Revised Microbiology (8): 251-259.

[8] Dapaola, A., Peeler, J. and Rodncky, G.E. (1995). Effects of Oxytetracychine-Mediated Feed On Antibiotic Resistance of Gram-Negative Bacteria in Catfish Ponds. Applied Environmental Microbiology (61): 2335-2340.

[9] Zhang, X.X., Zhang, T. and Fang, H.H.P. (2009). Antibiotic Resistance Genes in Water Environment. Applied Microbiology Biotechnology (82): 397-414.

[10] Ogbeibu, A.E. and Edutie, L.O. (2002). Effects of Brewery Effluents on the Water Quality and Rotifer. African Journal Environmental Pollution Health 1(2): 1-7.

[11] Akpomie, O.O., Buzugbe, H.S. and Eze, P.M. (2014). Effect of brewery effluent on the microbiological quality of Ikpoba river and surrounding borehole water in Benin city, Nigeria. British Microbiology Research Journal 5(1): 76-82, 2015. ISSN: 2231-0886.

[12] Ekhaise, F.O. and Anyansi, C.C. (2005). Influence of breweries effluent discharge on the microbiological and physicochemical quality of Ikpoba river, Nigeria. African Journal of Biotechnology 4 (10); 1062-1065.

[13] Cheesbrough, M. (2006). District Laboratory Practice in Tropical Africa. University of Cambridge ${ }^{\text {nd }}$ Edition Update Part 2. Pp. 63-70.

[14] Bauer, AW., Kirby, WM., Sheries, JC. and Turk, M. (1996).Antimicrobial sensitivity testing by agar diffusion method. Journal Clinical Pathology 45: 493-6.

[15] Baver, A.W., Kirby, W.M.M., Sherris, J.C., Turck, M. (1966). Antibiotics susceptibility testing by a standardized singles disc method. American Journal of Clinical Pathology 145: 493496

[16] Islam, M.T., M.R. Amin, S.M.R. Hoque and S.R. Alim, (2014). Microbial loads and association of enteropathogenic bacteria in ice-creams sold by street vendors at Dhaka city in
Bangladesh. Int. J.Pharm. Sci. Res., 5: 2436-2440.

[17] Winkler, U., Ruger,W. andWackernagew, L,. (1979). Bacterial, Phage and Molecular Genetics, Pp.-128. Berlin: Springer.

[18] Akpe, A.R., Ekundayo, A.O. and Esumeh F.I. (2013). Degradation of Crude oil by bacteria: A role for plasmid-borne genes. Global Journal of Scientific Frontier Research Biological Science 13(Issue 6 Version 1.0): 21-26.

[19] Dillon J. R. (1985). Recombinant DNA Methodology John Willey \& Sons, Canada. Pp81-83.

[20] Birnboim, H. C. and Doly, J. (1979). A rapid alkaline extraction procedure for screening recombinant plasmid DNA. Nucleic Acids Research 7:1513-1523.

[21] Sambrook J., Fritsch E. F., Maniatis T. (1989) Molecular cloning: laboratory manual, 2nd ed. Cold Spring Harbor Laboratory pres, Cold Spring Harbor, New York. ISBN 087969309-6.

[22] Dapaola, A., Peeler, J. and Rodncky, G.E. (1995). Effects of Oxytetracychine-Mediated Feed On Antibiotic Resistance of Gram-Negative Bacteria in Catfish Ponds. Applied Environmental Microbiology (61): 2335-2340.

[23] Forsberg, K.J., Reyes, A., Wang, B., Selleck, E.M., Sommer, M.O. and Dantas, G. (2012). TheShared Antibiotic Resistance of Soil Bacteria and Human Pathogens. Science (337): 11101111.

[24] Enabulele, O. I. and Orikpete, A. V. (2009). Extended spectrum B-lactamase production in Gram -negative aerobic isolate from diabetic wounds. Nig. J. Microbiol. 23(1):19611969.

[25] Esumeh, F. I., Akpe, A. R., Eguagie, O. E. (2009). Crude oil Degrading Capabilities of bacterial isolates from pawpaw (Carica papaya) and sweet orange (Citrus sinensis). A role for plasmid-mediated gene. Proceedings of the $1^{\text {st }}$ International Conference, Workshop and exhibition on Biotechnologies for Improved Production of Oil and Gas in the Gulf of Guinea, held in Abuja, Nigeria 1. April 1-3. 2009. BIPOG3 -4-34. Pp. $1-7$.

[26] Craig, Maclean (2016). Antibiotic Resistance in Bacteria. Journal Nature, Ecology and Evolution. Pp. 33-46. 